\title{
PREMISES FOR REFORMING THE REGULATION OF SECURITIES OFFERINGS: AN ESSAY
}

\author{
JAMES D. COX*
}

\section{INTRODUCTION}

One of the most significant characteristics of the Federal Securities Act of $1933^{1}$ is its durability. Even though the Securities Act has been amended several times since its enactment, the architecture and fundamental assumptions of the Act remain largely unchanged from their Depression-era beginnings. The Securities Act's underlying structure has not changed even though remarkable changes in securities markets have occurred, including the evolution of institutional investors' domination of securities markets, investment strategies and capital-raising occurring across borders, and the emergence of digital transmissions to replace the paper-based communication system that existed when the Act became law. The Securities Act's critics may see the continuing presence of regulatory tenets formed in the 1930's as further evidence of the necessity of radical reform of the U.S. securities laws. They may also argue forcefully that continuing adherence to the status quo reflects the political truth that powerful coalitions-regulators, investment bankers, accountants, and attorneys-have an interest in preserving the provisions of the Securities Act of 1933. ${ }^{2}$ Any change in the public offering process introduces the potential for lost rents for each of these constituencies; therefore, that change meets resistance. On the other hand, we can argue that the continuing vitality of a securities law enacted seven decades ago underscores the wisdom of its fundamental tenets, its inherent flexibility, and the SEC's wise oversight of its provisions.

Copyright (C) 2000 by James D. Cox

This article is also available at http://www.law.duke.edu/journals/63LCPCox.

* Brainerd Currie Professor of Law, Duke University.

1. 15 U.S.C. $§ 77 a-77$ aa (1994) [hereinafter Securities Act].

2. Many have invoked public choice theory to explain various actions by the SEC in terms of regulatory capture by various interest groups. See, e.g., HOMER KRIPKE, THE SEC AND CORPORATE Disclosure: Regulation in SEARCh of A Purpose 4, 18-20 (1979); Susan M. Phillips \& J. Richard Zecher, The SEC AND The Public InTERest 21-23, 60-89 (1981); Gregg A. Jarrell, Change at the Exchange: The Causes and Effects of Deregulation, 27 J.L. \& ECON. 273, 307 (1984); Donald C. Langevoort, The SEC as a Bureaucracy: Public Choice, Institutional Rhetoric, and the Process of Policy Formation, 47 WASH. \& LEE L. REV. 527 (1990); Jonathan R. Macey, Administrative Agency Obsolescence and Interest Group Formation: A Case Study of the SEC at Sixty, 15 CARDOZO L. REV. 909 (1994). 
In this article, I discuss six fundamental tenets that should guide the regulation of public offerings of securities. The approach followed in Part II assumes that regulation is to be re-examined from the ground up, with no political or regulatory constraints. Political reality is, however, re-introduced in Part III, which examines the reach of the exemptive authority that the SEC currently possesses, in order to determine whether the principles advanced in Part II can be carried out without Congressional action. Consideration of the scope of the SEC's authority to change its regulatory approach reflects a stark political reality: It is not likely that a major overhaul of the U.S. securities laws will be undertaken by Congress. Even if legislative reform were undertaken, it is unlikely to achieve better results than those that can be accomplished under the existing framework of the Securities Act.

\section{II}

\section{REGULATORY TENETS}

Whether it is the debates within Congress or the frequent expressions of courts, the incantations regarding the broad objective of the securities laws are the same: to provide full and fair disclosure for the protection of investors and to enhance the allocational efficiency of U.S. capital markets. These regulatory goals are not unique to the United States. The quest for improved allocational efficiency, deterrence of fraud, and enhanced investor decision-making are the objectives pursued by securities laws throughout the world community. ${ }^{3}$ Moving from these objectives to their implementation within a digital, globalized economy requires that the underlying tenets of regulation be isolated and reexamined. Six such tenets are considered below.

\section{A. The Filtration Process in the Digital Age}

The dominant theme animating the securities laws is the facilitation of informed, intelligent investment decisions. At the same time, the current view is that the individual investor does not read the prospectus produced by the registration process. The Securities Act's provisions support this hiatus between its stated objective and the reality of practice among individual investors by mandating only that the prospectus reach the investor after the security has been purchased. ${ }^{4}$ Nevertheless, the Securities Act still can be seen as fulfilling its objective despite this important omission, because its realistic objective transcends the information needs of the individual purchasing investor.

3. See International ORganization of SECURities COMMISSIONS, OBJECTIVES AND PRINCIPLES OF SECURITIES REGULATION 6 (1998) (identifying three core objectives of securities regulation as "the protection of investors, ensuring that markets are fair, efficient and transparent, and the reduction of systematic risk") (visited June 26, 2000) <http://www.IOSCO.org/docs-public/1998objectives.html>.

4. This occurs because the prospectus delivery requirements only apply to written offers so that if the investor's purchase is the result of an oral solicitation the securities laws mandate only that the prospectus accompany the written confirmation of the sale or the delivery of the purchased security. See Securities Act $\S 5(b)(1)(2), 15$ U.S.C. $\$ 77(e)$ (1994). 
It is important to recognize that regulation for the benefit of noninstitutional investors does not depend on such investors understanding or even accessing the information made available to them. To understand this point, consider that if markets were assumed to be comprised of only institutional investors, there would be no need for mandatory disclosure rules. If the market included only institutional investors, those investors could, through their bargaining power, extract from issuers the information they would require. However, in reality there is greater need for regulatory paternalism, because the market includes investors who lack the resources effectively to extract from the issuer the type of information that would have been made available in the idealized, institutional-investor only market. Mandatory disclosure thus takes over when self-help is not believed possible. ${ }^{5}$ Though institutional investors may still, and frequently do, extract from the issuer information that is not provided by the SEC's mandatory disclosure rules, those rules place individual investors on equal footing with their institutional counterparts as to certain core information. ${ }^{6}$

The genius of the current regulatory regime is that its social objectives can be achieved even though the information produced by the registration statement is not read, and the security does not need to be accurately priced by investors. The strength of the Securities Act is its nurturing of, and hence dependence upon, a filtration process by which information of the type that is exclusively in the possession of the issuer is made available to the public. The filtration process is not unique to the securities laws of the United States. In most developed countries, the securities laws emphasize the wide publication and distribution of information as central features of the regulation of public offerings. Any future revisions to the mandatory disclosure rules for public offerings should, therefore, retain the goal of broadly distributing investorrelevant information, without also requiring that individual investors actually receive the information set forth in the registration statement.

The first step in the present filtration process is the submission of information to the SEC. During the period when the registration statement is with the SEC, substantial selling efforts occur. ${ }^{7}$ Nevertheless, the deliberateness of the SEC staff's review of material filed by unseasoned issuers provides an important buffer period before the registration statement becomes effective. This waiting period serves the underwriters' efforts in promoting the offering and also provides time for investors to weigh their purchase of the security. Analysts and other market intermediaries also can use this time to evaluate the of-

5. The best illustration of the securities laws' embrace of self-help is Rule 144A, 17 C.F.R. $\S$ 230.144A (1999), which facilitates the distribution of unregistered securities to "qualified institutional investors" without mandated disclosure.

6. See Rule 502(b)(iv), 17 C.F.R. $§ 230.502$ (b)(iv) (1999) (requiring that offerings made pursuant to Regulation $\mathrm{D}$ that include non-accredited investors require that the issuer provide to those investors a summary of any material information the issuer has disclosed to accredited investors).

7. See James D. Cox et Al., Securities Regulations: Cases and Materials 293-98 (2d ed. 1997). 
fered security. Investors who were eager when first approached have time to change their minds before the security's sale can be confirmed. Furthermore, review by the SEC also assures a detached and careful assessment of the registration statement's completeness.

To illustrate the functions of the filtration process for seasoned issuers, consider the modern day effects of SEC v. Ralston Purina Co., ${ }^{8}$ the most important case to interpret the Securities Act. In Ralston Purina, the Supreme Court held that Ralston Purina could not avoid registration of securities under the private offering exemption when the offerees included, among others, a bakeshop foreman, a chow-loading foreman, and a clerical assistant. ${ }^{9}$ The court reasoned that these offerees needed the mandatory disclosures provided by registration because their positions did not provide them with "access to the same kind of information that the [Securities] Act would make available in the form of a registration statement." 10 Because of its narrow definition of the private offering exemption, Ralston Purina had the effect of increasing the regulatory demands of the Securities Act. ${ }^{11}$

Even though the Supreme Court's focus in Ralston Purina is on the information needs of unsophisticated offerees such as the chow-loading foreman, consider just how little information the chow-loading foreman receives, even today. Because Ralston Purina is a seasoned issuer with an equity float which enables it to register any of its securities on Form S-3, ${ }^{12}$ the only information the Securities Act requires the issuer to provide the chow-loading foreman, or any other purchaser, is distributed when the sale is confirmed. ${ }^{13}$ Instead of requiring an offering brochure made pursuant to a private offering that sets forth extensive information about Ralston Purina, the registration of the offering on Form S-3 today mandates that the information provided to the purchaser focus on the offering itself and not the issuer as such. The investor must then use her own efforts to access the registrant's SEC filings in order to obtain information about such seasoned issuers. For companies eligible to use the SEC's integrated dis-

8. 346 U.S. 119 (1953).

9. See id. at 121 .

10. Id. at $125-26$.

11. Ralston Purina has had a regulatory impact in at least three ways. First, it demands that all offerees either have access to the type of information that registration would compel or disclosure of that information. See, e.g., Doran v. Petroleum Management Corp., 545 F.2d 893, 903 (5th Cir. 1977). Second, lower courts have interpreted Ralston Purina to introduce a sophistication requirement for the exemption's availability so that all offerees must have sufficient financial experience or training to evaluate the offerings. See, e.g., Mark v. FSC Securities Corp., 870 F.2d 331, 335-36 (6th Cir. 1989). Third, most significantly, Ralston Purina guides the determination of what constitutes a "distribution" when determining whether a resale of a security must be registered with the SEC. See Gilligan Will \& Co. v. SEC, 267 F.2d 461, 466 (2d Cir. 1959).

12. See Form S-3, General Instructions IB $1 \& 2$ (conditioning forms' availability for primary offerings on issuer having an aggregate market value of voting and non-voting common equity of $\$ 75$ million held by non-affiliates or the issuer offering non-convertible investment-grade security).

13. Rule 434, 17 C.F.R. $\S 434$ (1999), allows the information required to be set forth in a prospectus to occur over multiple documents in serial fashion so that when all releases are combined, the information required for a final prospectus is complete under the requirements of Section 5(b), 15 U.S.C. § 77e (1994) before the sale may be confirmed and the securities delivered. 
closure procedures, the social benefits of registration created by Ralston Purina's narrow construction of the private offering exemption lie in the process of registration rather than in the information provided to any particular investor.

More important, during the time between the registrant's filing of the draft registration statement with the SEC and the registration statement becoming effective - the so-called waiting period-the issuer's disclosures are circulated widely among market professionals, resulting in an opportunity for a critical assessment of the issuer and its disclosures. The filed registration statement complements the duties brokers owe their clients, so that the registration statement indirectly protects investors. First, because brokers are under an affirmative obligation to have a reasonable basis for any recommendation made to their clients, ${ }^{14}$ the registration statement is an important means, if not the sole one, for the broker to fulfill this obligation. Second, the broker should understand that any material dissonance between the recommendation and information that could be reasonably determined from the registration statement may result in liability. ${ }^{15}$ Under Section 12(a)(2), the distributing broker is liable for any material untruth, unless she can establish that she was unaware of the untruth and could not have discovered it by the exercise of reasonable care. ${ }^{16}$ Third, when recommending a security, a broker must have a reasonable basis to believe that the security is suitable for the customer. ${ }^{17}$ The registration statement allows the broker to determine the suitability of the recommended security for various customers. Finally, the registration statement allows the broker to compare various investment opportunities in order to determine which is best for her clients. The availability of comparative information about seasoned and unseasoned companies, whether purchased in the primary or secondary market, facilitates such decision-making. This factor, in turn, informs the pricing of these offerings, because the demand measured during the waiting period guides the issuer and its underwriters in determining both the price and amount of securities to offer. The mechanisms that currently shape the filtration process serve all of these functions. The process, therefore, does not depend on the retail investor actually reading or understanding the registration statement. The mechanism works even though the chow-loading foreman receives very little information about the issuer.

The paramount objective of the filtration process is the wide dissemination of information relevant to the security being offered. As initially conceived during the paper-based society of the 1930's, and continuing as a feature of the securities laws today, the medium of dissemination is the prospectus. The prospectus is the exclusive means for written offers prior to the registration statement becoming effective; other written materials may be circulated after the registration statement becomes effective so long as they are preceded or ac-

14. See, e.g., Hanly v. Securities and Exchange Commission, 415 F.2d 589, 597 (2d Cir. 1969).

15. See 15 U.S.C. $77 k(\mathrm{a})$.

16. See 15 U.S.C. $\$ 77 l(a)(2)$ (1994).

17. See, e.g., Clark v. John Lamula Investors, 583 F.2d 594, 600 (2d Cir. 1978). 
companied by a final prospectus. ${ }^{18}$ Additionally, before a sale may be confirmed or the security delivered, a final prospectus must be sent to the customer. ${ }^{19}$ Fortunately, technology and an understanding SEC have liberated the filtration process from its paper-based beginnings. Today, issuers and their underwriters enjoy many options via the Internet with respect to satisfying the delivery requirements for the prospectus. ${ }^{20}$

The teachings of market efficiency provides a most useful paradigm for considering mechanisms to fulfill the filtration process. A tenet that should guide regulation of the filtration process is that securities that will be offered in what is reasonably believed to be an informationally efficient market should enjoy instant access to that market. For the issuers of securities in an informationally efficient market, registration would be a true company registration procedure under which the sale of the security is viewed not as the cause of a new registration process, but instead as an event that triggers the issuer's duty to update its Exchange Act reports (and to pay any SEC mandated registration fees). With a belief that the security will be traded in an informationally rich and efficient market, the key focus becomes information about the issuer publicly available. For a subset of qualified issuers, there should be no requirement to deliver a prospectus to investors, regardless of the qualities of any particular investor. Self-help, not mandatory delivery, should be the governing principle for investors purchasing a security from this class of issuers. Prospectus-type information in this case would be available to investors and distribution participants via the issuer's EDGAR filings with the SEC.

The most challenging policy questions for such a company registration system are: (1) how to develop reasonable standards regarding the issuer's duty to update the information set forth in its Exchange Act reports when the security offering is not close in time to the previous report; ${ }^{21}$ and (2) how to determine the focus of the due diligence liabilities currently imposed upon senior officers, directors, underwriters, and certain experts, such as the accountants who have certified the issuer's financial statements. ${ }^{22}$ The political burdens of addressing the duty to update, as well as the various parties' due diligence obligations, are the costs necessary to reap the benefits of a true company registration process, namely nearly instant access to capital markets.

For securities that are not traded in an informationally efficient market-IPOs and small capital reporting companies-the regulatory approach would largely resemble what exists today: The registration statement would be

18. See Securities Act $\S 5(b)(1), 15$ U.S.C. $\S 77 e(b)(1)(1994)$.

19. See Securities Act $\$ 5(\mathrm{~b})(2), 15$ U.S.C. $\$ 77 \mathrm{e}(\mathrm{b})(2)$ (1994).

20. See generally Use of Electronic Media for Delivery Purposes, Securities Act Release No. 7233, 60 SEC Docket 1091 (Oct. 6, 1995).

21. See Donald C. Langevoort, Toward More Effective Disclosure for Technology Enhanced Investing, 75 WASH. U. L.Q. 753, 770-77 (1997).

22. See James D. Cox, The Fundamentals of an Electronic-Based Federal Securities Act, 75 WASH. U. L.Q. 857, 875-86 (1997); Donald C. Langevoort, Deconstructing Section 11: Public Offering Liability in a Continuous Disclosure Environment 63 LAW \& CONTEMP. PROBS. ?? (Summer 2000). 
vetted with the SEC, its contents would be distributed widely among investors and market professionals, and the issuer and others will be subject to demanding liability standards in the case of misrepresentations that appear in the registration statement. ${ }^{23}$ There is little reason to retreat from these requirements for such issuers. Not only does this group of firms pose the greatest risk of fraud to companies ${ }^{24}$ but they are not followed closely by analysts and institutional investors. Therefore, additional steps must be taken to assure that the information in these companies registration statement has an impact on investors. Moreover, the robust nature of the IPO market during the most recent bull market suggests that regulation has not impeded capital formation for start-up companies. ${ }^{25}$

\section{B. Company Disclosures versus Public Offerings}

For average consumers, information is a good thing, and even better if it comes at no cost to them. At the same time, there are real costs to produce information that will be truly useful. These costs do not necessarily arise from the actual generation of the information. Investors desire the same types of information that a firm's managers need to be responsible stewards of the firm. Except for liability concerns that accompany any public disclosure of financially relevant information, the marginal costs of generating the information required for an SEC filing are minimal because this information is already before the company's officers. However, mandatory disclosure introduces many indirect costs. One source of these indirect costs can be traced to the consequences that flow from making the information available, notably the ever-present liability costs that are incurred if information that is disclosed is challenged as being materially misleading. Issuer liability is absolute under the Securities Act, and its managers, underwriters, and auditors face liability unless they satisfy their demanding due diligence defense. ${ }^{26}$ Another potential indirect cost is the possibility that information known to managers, if disclosed, would erode competitive advantages the firm has or hopes to obtain. ${ }^{27}$ Each of these costs, although significant, are nevertheless minor compared to what firms view as the most sig-

23. As envisioned here, there should be no additional requirement that the prospectus actually be received by a non-requesting investor before the sale is confirmed. As seen earlier, the strength of the filtration system lies in the information being available for distribution to participants and to the investor. Recently, the SEC proposed changes in its prospectus delivery requirements that would as a practical matter, have required actual receipt of the prospectus before the sale was confirmed. See Securities Act Release No. 7606A, 63 Fed. Reg. 67,174 (Dec. 4, 1998) [hereinafter Aircraft Carrier].

24. See Accounting Industry Group Releases Fraud Study, Fed. Sec. L. Rep. (CCH) No. 1869 (Apr. 14, 1999) (reporting the results of a study of 200 randomly selected cases prosecuted by the SEC between 1987 and 1997 that revealed that most instances of fraudulent reporting involved companies with a market capitalization below $\$ 100$ million).

25. See 17 SEC ANN. REP. (1998) (reporting $\$ 257$ billion raised in IPOs for 1998).

26. See Securities Act $\S 11(b), 15$ U.S.C. $\S 77 k(b)$ (1994).

27. See Merritt B. Fox, Securities Disclosure in a Globalizing Market: Who Should Regulate Whom, 95 MICH. L. REV. 2498, 2550-52 (1997) (stating that increased disclosure reduces rewards for product or market developments) [hereinafter Fox, Who Should Regulate Whom]; Edmund W. Kitch, The Theory and Practice of Security Disclosure, 61 BROOK. L. REV. 763 (1995). 
nificant cost of mandatory disclosure, namely, the delay, and hence uncertainty, that compliance with mandatory disclosure requirements inflict on issuers and investors in the capital formation processes.

Mandatory disclosure rules introduce substantial market uncertainties to investors and issuers. The delays inherent in complying with current regulatory requirements for conducting a public offering entail real costs to their issuers, which are significant even for well-established companies. Herein lies the true cost of mandatory disclosure. Consider the current outcry surrounding the SEC's proposal ${ }^{28}$ to withdraw from its position in the Exxon Capital no-action letter, where the SEC approved the procedure for unregistered investmentgrade preferred stock or debt securities to be distributed to institutional investors without registration, pursuant to an undertaking by their issuer to register a different class of securities into which the unregistered security later could be converted. ${ }^{29}$ The operative effect of transactions carried out pursuant to Exxon Capital is that the regulatory step for distributing the security is separated from the actual capital-raising process. The unregistered debt security can, therefore, be priced and sold in a market known to its issuer and its purchasers. To have delayed that sale until a registration statement was filed with the SEC and had become effective would subject the entire process to non-trivial market risks during the regulatory term. Because offerings of unregistered debt made in reliance upon Exxon Capital customarily occur through disclosure documents that set forth information of the type disclosed in the registration statement, ${ }^{30}$ the costs their issuers seek to avoid are not the direct costs to produce information or the indirect costs related to any resulting loss of competitive advantage. Rather, issuers seek to avoid the costs associated with market risks incidental to the registration process. A central consideration in any future regulation of public offerings, therefore, should be the avoidance of regulatory requirements that visit unnecessary market risks on issuers and investors.

Data reveal that integrated disclosure, even though available only to seasoned issuers, involves costly delays that necessarily introduce market risks to the capital raising process. ${ }^{31}$ Because of these delays, seasoned issuers increas-

28. See Aircraft Carrier, supra note 23, Section H.

29. Exxon Capital Holdings Corp., SEC No-Action Letter, WSB File No. 051688008 (May 13, 1988) involved the private placement of unregistered preferred stock that would be exchanged a few months later for registered preferred shares. Since Exxon Capital, the SEC has expanded this financing option positions taken through many subsequent no-action letters. See, e.g., Shearman \& Sterling, SEC No-Action Letter, [1993 Transfer Binder] Fed. Sec. L. Rep. (CCH) II76,704, at 78,039 (July 2, 1993) (stating that broker dealer enjoys status of underwriter in an $\mathrm{A} / \mathrm{B}$ exchange so that it must deliver a prospectus for the exchanged security); Morgan Stanley \& Co., SEC No-Action Letter, [1991-1992 Transfer Binder] Fed. Sec. L. Rep. (CCH) II 76,018, at 78,884 (June 5, 1991).

30. See Bradley Jay Gans, The Mechanics of Rule 144A/Regulation S Underwritings in Securities Offerings, in SECURITIES OFFERINGS: WHAT ISSUERS' \& UNDERWRITERS' COUNSEL NEED TO KNOW Now 2000 357, 449-51 (Practicing Law Ins. ed., 1998).

31. See SeC Rep. of the Advisory Committee on the Cap. Formation \& Reg. Processes app. A, tbl. 2 (July 24, 1996), reprinted in [1996-1997 Transfer Binder] Fed. Sec. L. Rep. (CCH) II 85,834 [hereinafter Wallman Commission Report] (reflecting that non-shelf offerings on Form S-3 are with the SEC 9.3 days before becoming effective and an additional 22.6 days with the issuer; the time 
ingly favor exemptions that provide quicker access to markets, such as those used in Exxon Capital, even though such exempt offerings entail non-trivial costs because a security sold pursuant to an exemption does not enjoy the same liquidity as does a registered security. ${ }^{32}$

The major cause for delay under the current integrated disclosure system is Section 11's imposition of liability on the issuer and others for any misrepresentation in the registration statement when it becomes effective. ${ }^{33}$ Section 11's demands are not significant for information pertaining to the offered transaction itself, such as the type and amount of the security to be offered, or information about the underwriting, or the planned use of the proceeds. Section 11's full impact is felt with respect to information incorporated into the registration statement from reports previously filed by the issuer pursuant to its continuous reporting obligations under the Exchange Act. Because those reports are not prepared pursuant to an absolute liability standard for the issuer, or to an obligation that an issuer's officers, directors, or underwriters carry out a reasonable investigation to assure themselves that the filed information is free of material omissions or misstatements, the issuer and its distribution participants must take steps to assure themselves of their reports' accuracy. ${ }^{34}$ Thus, the delay inherent in the SEC's integrated disclosure procedures is not due to the underlying transaction, but instead is a result of the incorporation of on extensive information about the issuer that was not as carefully scrutinized because of the demands of Section 11 when it was initially filed. We can see, therefore, that the major impediment to the unfettered use of integrated disclosure by seasoned issuers is that prevailing liability standards force issuers to see the registration as a significant transaction cost for raising capital. As such, the cost of raising capital through registration will be evaluated in light of alternative exempt methods and their associated costs. Even with registration, the chowloading foreman still only gets a confirmation slip.

The regulatory objective should not be to provide the chow-loading foreman with more information, but instead to provide the same protection but with less delay to the issuer. I have argued elsewhere that this cannot occur as long as the entire set of Section 11 responsibilities remains fixed when the registration

with both the SEC and the issuer for shelf registration is significantly longer than for a non-shelf, 17.5 days and 36.3 days, respectively).

32. A security offered through Rule $144 \mathrm{~A}$ is a restricted security and, therefore, may be resold pursuant to the SEC's resale safe harbor, Rule 144, 17 C.F.R. $\$ 230.144$ (2000), or pursuant to another available exemption.

33. The issuer's liability is absolute, whereas that of the underwriters and certain others is subject to their establishing the due diligence defense provided by the statute. See Securities Act of $1933 \S 11$ (b)(3), 15 U.S.C. $\$ 77 \mathrm{k}(\mathrm{b})(1994)$.

34. Misstatements or omissions in reports filed pursuant to the Securities Exchange Act's continuous reporting requirements are governed by antifraud provisions that condition liability on the misrepresentation being committed with scienter. See Securities Exchange Act of 1934 § 10(b), 15 U.S.C. § 78j(b) (1994); Rule 10b-5, 17 C.F.R. § 240.10b-5 (1999); Securities Exchange Act of 1934 § 18, 15 U.S.C. $\S 78 \mathrm{r}(1994)$. 
statement becomes effective. ${ }^{35}$ Redistributing the various Section 11 responsibilities to other points in time, thereby reducing the regulatory costs of registration, holds the greatest appeal for the seasoned issuer. Companies going public should approach their disclosure obligations carefully. Not surprisingly, there are no proponents for lightening the present regulatory structure for IPOs. ${ }^{36}$ On the other hand, Section 11 remains a daunting speed bump in the path of seasoned issuers contemplating a public offering. Any important reform of the regulatory procedures must lift the transaction orientation that presently dominates the process of raising capital, which would occur through a true company registration procedure for seasoned companies.

Company registration is not a new idea, but it is one whose time has fully come. Four decades ago, Milton Cohen mused how different the registration process would be if, in 1933, the 73rd Congress had dealt with the subject of continuous disclosure before taking up the narrower topic of regulating public offerings. ${ }^{37}$ Later, the Federal Securities Code, sponsored by the American Law Institute, called for a version of company registration. ${ }^{38}$ More recently, a blue ribbon committee created by the SEC made the company registration system the core element of its proposals. ${ }^{39}$ What is new about the vision offered here is that none of the earlier ones call for a company registration system to separate Section 11 liability from the registration process; each of the earlier proposals has retained contemporary Section 11 responsibilities so that the delays and resulting market risks inherent in registering securities would continue.

A true company registration procedure should treat the public offering of securities as the equivalent of a material event that requires the issuer to update its Exchange Act reports before the offering can occur. This procedure could be implemented under the current regulatory framework. The only challenging issue is to discover which portions of the current Section 11 responsibilities must be lifted to assure that a true company registration process could exist. Liability standards for a company registration system entail many far-reaching questions that go beyond the focus of this article. Here, it is sufficient to say that the attestation standard for senior officers and directors, as well as the due diligence standard for the auditors of the issuer's financial statements, would continue to apply. The primary change for the proposed company registration statement would be to narrow the focus of the underwriters' undertaking to encompass only information regarding the description of the issuer's current and future business prospects and its proposed use of the proceeds. Underwriters

35. See James D. Cox, The Fundamentals of an Electronic-Based Federal Securities Act, 75 WASH. U. L.Q. 857, 872-82 (1997).

36. To be sure, there are those, discussed later in this article, who question the social benefits of mandatory disclosure and, therefore, can be seen as championing relaxation of not just the IPO process but disclosure procedures for all securities transactions. However, this voice was not heard at the roundtable discussion, summarized in this symposium, where the participants shared the view that the regulatory demands for IPO were optimal.

37. See Milton H. Cohen, Truth in Securities Revisited, 79 HARV. L. REV. 1340, 1366-67 (1966).

38. See FEDERAL SEC. CODE (1978).

39. See Wallman Commission Report, supra note 31. 
would not have any responsibility for other types of financial information, such as interim financial information. ${ }^{40}$

\section{Busting Up the Registration Statement Monopoly}

Regulation works best when it complements, rather than distorts, the social and commercial environment within which regulated transactions occur. Any securities provision should, therefore, pay close attention to how issuers, underwriters, and investors function. For example, the SEC's releases dealing with the electronic delivery of the prospectus reflects the growing influence of the Internet as the medium connecting investors to the underwriters of a distributed security. ${ }^{41}$ Just as the Internet can be the backbone for the Securities Act's filtration system, it can also pose the most serious challenge to one of the Act's major assumptions: The registration statement is the sole means for the issuer to disseminate information that will pique investors' interest in its security.

The SEC's historical position is that the registration statement should enjoy a monopoly position with respect to information bearing on the issuer. This has been the basis for its requirement that the issuer and its distribution participants abstain from communications, except those embodied in the registration statement, that would stimulate investor interest in the security. ${ }^{42}$ Not only does this position impose a quiet period before filing the registration statement, it also forbids the circulation of written communications to possible investors, except for a preliminary prospectus prior to the registration statement becoming final. ${ }^{43}$ Some important relief from this prohibition is provided to issuers who are subject to the Exchange Act's continuous reporting requirements. ${ }^{44}$ In contrast, a

40. Moreover, the SEC would embrace a due diligence safe harbor established by representatives of the underwriters' industry that would set forth good practices which, if followed, would constitute compliance with their due diligence obligations.

41. See Securities Act Release No. 7233, supra note 20; see also Use of Electronic Media, Securities Act Release No. 7856, 65 Fed. Reg. 25,843 (May 4, 2000).

42. This restriction commences when the company is "in registration" which begins at least when the issuer has reached a preliminary agreement with its underwriter to undertake a public offering. See Guidelines for the Release of Information by Issuers Whose Securities are in Regulation, Securities Act Release No. 5180, n.1 [1970-1971 Transfer Binder] Fed. Sec. L. Rep. (CCH) II 78,192 (Oct. 16, 1971). The SEC's elevation of the registration statement to its monopoly-like position is embodied in a series of class pronouncements. See id.; Publication of Information Prior to or After the Filing and Effective Date of a Registration Statement Under the Act, Securities Act Release No. 5009 [Transfer Binder 1969-1970] II 77,744 (Oct. 7, 1969); Securities Act Release No. 3844 (Oct. 8, 1957). For careful reviews and criticisms of the SEC's position, see Eric Chiappienelli, Gun Jumping: The Problem of Extraneous Offers of Securities, 50 U. PITT. L. REV. 457 (1989); Joseph P. Richards \& Joseph E. Reece, Gun Jumping, 26 REV. SEC. \& COMMODITIES REG. 1 (1993).

43. Securities Act $\S 5(\mathrm{~b})(1), 15$ U.S.C. $\$ 77 \mathrm{e}(\mathrm{b})(1)$ (1994), in tandem with the definition of prospectus in Securities Act $\S 2(10), 15$ U.S.C. $\$ 77 b(10)$ (1994), prohibits the circulation of written, electronic, or telephonic materials that do not replicate what is in the prospectus unless such materials are accompanied or preceded by a prospectus that exists after the registration statement has become effective.

44. Rules 137-139, 17 C.F.R. $\S \S 230.137-230.139$ (1999), permit broker-dealers to publish investment reports meeting certain conditions even though the reports involve a security that is in registration. 
veil of silence is imposed on the use of analysts reports by distribution participants for non-reporting companies.

Why should the registration statement enjoy such a monopoly position? Consider the leading gun-jumping SEC enforcement action, Carl M. Loeb, Rhoades \& $\mathrm{Co}^{45}$ where, prior to filing its registration statement, Arvida Corporation issued a series of press releases announcing that industrialists Arthur Vining Davis would soon undertake a public offering to provide a large amount of capital needed to develop new communities, industrial parks, and recreational areas. One release stated that the registration statement was being prepared and identified the offering's lead underwriters. ${ }^{46}$ The press releases consistently emphasized that the properties would be developed in an orderly and timely manner so as to maximize each parcel's value. ${ }^{47}$

Several regulatory objectives are fulfilled by the SEC's interpretation of the term "offer" to include any communication that will condition investors' interest in the security, so that all written offers prior to the registration statement becoming effective occur only through a preliminary prospectus. Thereafter, other materials may be circulated so long as they are preceded or accompanied by a final prospectus. By interpreting the term "offer" broadly, the information is directed through the filtration process and is sanitized by the rigorous liability standards of Section 11. Without gun-jumping restrictions, investors' interest in the distributed security would be stimulated by information that lacks the same credibility as information that is bonded by Section 11's liability standards. Thus, if the information released by Arvida Corporation about its upcoming venture had been released instead through a registration statement, several sobering facts would have been disclosed; for example, much of the offering's proceeds would not be used for actual development of the land but instead to discharge indebtedness on the property. ${ }^{48}$ Investors also would have learned that much of the acreage controlled by Arvida was remote from the parcels that would in fact be developed. ${ }^{49}$

A second benefit of gun-jumping regulation arises out of the genuine fear that misinformation that is released about a security will not be overcome by subsequent disclosure of accurate information about the security. To be sure, if sufficient time lapses between the misleading information's release and the investor's decision to purchase the promoted security, there is less reason to believe that the misleading information assumes any significance in that decision. Registration and its accompanying quiet period introduce such a buffer period of time. The present embargo on the distribution of any promotional information once the company is in registration provides a cooling-off period between the misleading report and the accurate report.

45. See 38 S.E.C. 843 (1959).

46. See id. at 845 .

47. See id. at 846 .

48. See id. at 854 .

49. See id. 
A third benefit of gun-jumping regulation is that, if issuers could freely release information about their future offerings and the riches that will befall the owners of the security, issuers may be tempted not to register the offering at all. With the unregulated announcement, the issuer may find itself overwhelmed by investors too impatient to await the issuer's compliance with the registration process. Faced with the bird in its hand versus those uncertain to be in the bush when the registrant completes its path through the SEC's gauntlet some four to six months later, the one in hand may be too tempting to resist.

A fourth benefit flowing from the SEC's strict interpretation of Section 5 is that in many cases, the gun-jumping regulation greatly lightens its enforcement efforts. Had the SEC sought to enjoin Arvida and its distribution participants from issuing misleading reports, it would have been confronted with the need to prove the materiality of the misrepresentations and that they were committed with scienter. ${ }^{50}$ In contrast, a Section 5 violation requires only that the communication could have the effect of conditioning investor interest. Though making out a case of fraudulent misrepresentation would seem to be an easy matter in Carl M. Loeb, Rhoades \& Co., one can well imagine other instances where the enforcement effort based on misrepresentation would be more problematic.

These four objectives are worthy, but they do come at the price of discouraging the publication of independent analyses of the offering. Present day gunjumping restrictions choke the flow of issuer-relevant information into capital markets. Moreover, each of the above objectives is not without qualification regarding its social benefits. First, an issuer may well choose to include only the information it is required to disclose in the registration statement. Other information not included in the registration statement may be released orally after the registration statement is filed or distributed in writing after the registration statement becomes final. Thus, one effect of gun-jumping may be that it delays information flows, rather than changing the quality of information that reaches the investor.

Second, we may well doubt the value to investors of a communication that occurs months or even weeks before the registration statement becomes effective and sales are consummated. One study found that the average length of time for a filed registration statement to become effective for an IPO is 38.9 days. ${ }^{51}$ Is it likely that statements made more than a month before a sale can be lawfully consummated still have an effect on the decisions of the security's purchaser? ${ }^{52}$ Investors may be bullish on the issuers, but bulls do not have the memories of elephants. Certainly the "lie first told" postulate must have some

50. See, e.g., SEC v. Aaron, 446 U.S. 680 (1980).

51. See Wallman Commission Report, supra note 31, at 48, tbl. 2 (showing findings based on a sample of 641 issuers of common stock January 1994 through December 1995).

52. Because the quiet period begins at least when the issuer reaches a preliminary understanding with its underwriter, the actual quiet period imposed by the Securities Act is at least 80 days: The above cited study also found that the average IPO issuer has spent 39.3 days drafting the registration statement before it is filed with the Commission. See id. 
serious time boundaries, and a reasonable boundary should be measured in days, not months.

Third, issuers may need some protection from overly aggressive investors who insist that they have a chance to purchase the security immediately and not some months hence when the registration statement becomes effective. At the same time, the automatic rescission remedy provided to those investors by Section 12(a)(1) should cause the issuer to appreciate the win-win situation a statutory "put" creates with regard to eager investors. ${ }^{53}$ Also, there is a growing awareness that issuers need to "test the waters" before rushing into the costly and time-consuming registration process. It may well be that the issuer's registered offering will not have broad appeal in case the issuer must raise its capital in a more focused exempt offering targeted toward institutional investors. Current gun-jumping prohibitions prevent this flexibility.

Finally, there appears to be little evidence that the SEC needs the automatic violation provisions of Section 5 to enhance its enforcement of misrepresentation cases. Certainly, there is much to be said for the principle that the capital formation process should not be held hostage to the expediency of the SEC's Division of Enforcement. Thus, there are many reasons to doubt that the present interpretation of Section 5's reach is socially useful. What appears more desirable is a regulatory approach that simultaneously encourages the release of information and recognizes that today's commercial climate is far richer from an informational standpoint than the one that prevailed in the 1930's.

An informative web page is a fixture of doing business today, just as the smoke stack was in 1933. Digital transmissions have nurtured an increasingly rich and dynamic information environment that has seamless connections between the commercial and capital raising activities of companies. Technology calls for a serious retreat from the view that the registration statement should enjoy a monopoly on information concerning the issuer, as well as a recognition that any company registration system is necessarily inconsistent with the idea that the registration statement is the exclusive source of the type of information included therein. Thus, seasoned companies that will be subject to a true company registration system, as well as their distribution participants, should face no restrictions upon their release of information during the registration process. The SEC's restrictions on information flows should be confined to companies that are outside the company registration procedures.

For non-seasoned companies, there can be a regulated period, no longer than 30 days prior to the expected effective date of the registration statement becoming effective, ${ }^{54}$ during which any written or electronic public releases of information by the issuer or its distribution participants would be filed with the SEC. The filed information would not, however, be part of the registration

53. See 15 U.S.C. $\$ 77 l(a)(1)(1994)$.

54. The SEC's Aircraft Carrier calls for a communication blackout period commencing for nonseasoned companies 30 days before the registration statement is filed and for other companies fifteen days before the security is offered for sale. See Aircraft Carrier, supra note 23, at 117. 
statement and hence outside the scope of Section 11. Rather, the information would be prophylactic in nature, filed in order to provide a basis for the SEC's staff to assess the accuracy of these non-registration statement materials in light of the material contained in the registration statement. No filing would be required if there were no release within the restricted period. If the staff had concerns over dissonance between the non-registration statement information released during the restricted period and the registration statement, this conflict could be resolved between the issuer and the staff, perhaps by corrective disclosures or by delaying the effectiveness of the registration statement or both.

In broad overview, the focus of the registration process should be to make information of the type the SEC believes is important to investors publicly available. The information's trustworthiness, as seen earlier, is heightened through the review process at the SEC, the Section 11 liability standards, and the subjection of the information to public scrutiny through the filtration process. Foreclosing the simultaneous distribution of other types of information, whether it comes from analysts or from the issuer's marketing department, makes the registration statement's disclosures more important, but it does not render unimportant non-registration statement types of information. One possible goal served by foreclosing the release of information outside the registration statement is that forcing the information into the registration statement may have the concomitant effect of making it more trustworthy. This is not unlike the belief that integrated disclosure would lead to more reliable Exchange Act reports for issuers who incorporated those reports into their Securities Act registration statements. However, there is no evidence that the quality of Exchange Act reports has improved as a consequence of integrated disclosure or that issuers have relocated information to their registration statement.

The monopoly paradigm may have a useful role to play in considering the type of information that must be disclosed in SEC filings. Registration should compel the release of a core set of information that is exclusively within the unique possession of the issuer. There is no reason to compel issuers to disclose information that is independently available. Thus, foreclosing the distribution of the analyst's reports only makes the registration statement more important; but it does not reduce the possible importance of the analyst's report. The SEC's challenge is to identify the types of information that are uniquely in its registrant's possession so that mandatory disclosure is appropriate. This regulatory objective provides a useful standard for understanding that information regarding the issuer. Thus, information produced in the registration statement produced will be examined by investors in the contemporary information environment regarding the issuer so that the registration statement is not the exclusive source of information about the issuer. The registration statement can, however, provide a highly credible and sober base against which other types of information can be considered. Thus, it is time to reverse course and steer away from the monopoly position presently enjoyed by the registration statement. The regulatory paradigm should instead be that the registration statement supplements information that is already available about the issuer. 
D. Focusing on the Nature of the Security and its Purchaser

Among the interesting issues posed by an electronic-age securities act is the scope of exemptions from registration and the role of the state blue sky administrator for exempted offerings. The recently enacted National Securities Markets Improvement $\mathrm{Act}^{55}$ underscores the fact that though these issues are related, Congress's recognition of an exemption from federal regulation is not a license for the states to provide their own brand of regulation. Thus, the Act includes in its designation of a "covered security" that is exempt from state registration procedures those securities offered pursuant to the Securities Act's private offering exemption. ${ }^{56}$ By so acting, Congress expressed its belief that if the issuer met the exemption's criteria no further regulatory protection for investors is necessary. One can easily fault Congress for not according other federally exempt offerings, such as those made under Regulation A, the same dignity as private offering exemptions so that by satisfying the minimal federal disclosure requirements, the issuer is shielded from any further burdens imposed on it by the states. ${ }^{57}$ Nevertheless, the National Capital Markets Improvements Act can be seen as an important initial step toward rationalizing a role for state regulation in today's highly fluid markets.

A fertile area upon which to focus deregulatory efforts are the qualities of the purchaser rather than on the qualities of the offeree in determining whether an exemptions criterion has been satisfied. ${ }^{58}$ Certainly, it was easier in a paperbased society to focus on the offeree's qualities; issuers could more easily track the physical movement of their offering brochures by, for example, numbering the brochures and then matching the potential purchasers approached with a specific offering brochure. The "forward" function on e-mail software deprives the issuer of knowledge of the ultimate recipients of its offering materials. Though there were plenty of opportunities for leakage in the paper-based system, it is more difficult with the Internet to continue to turn a blind eye to the impracticability of limiting the offers only to those meeting a predetermined set of criteria. Thus, the important deregulatory step taken by the SEC in adopting Rule 506, which liberalized the private offering exemption by focusing on the qualities of purchasers, should become the standard approach for all electronic age securities act exemptions. ${ }^{59}$

55. See Pub. L. No. 104-290, 110 Stat. 3416 (1996).

56. Securities Act $\S 18(b)(4)(D), 15$ U.S.C. $\$ 77 r(b)(4)(D)$ (1994).

57. See Rutherford B. Campbell, The Impact of NSMIA on Small Issuers, 53 BUS. LAW. 575, 58283 (1998).

58. Only in Regulation D, Rules 501-508, 17 C.F.R. $\S 230.501-508$ (1999), does the Commission ignore the qualities of the issuer's offerees. Thus, offers that do not comply substantially with the requirements of Regulation D must then take steps to assure that all offerees, and not just purchasers, are, for example, sophisticated. See SEC v. Life Partners, Inc., 912 F. Supp. 4, 10 (D.D.C. 1996) (ruling that issuer could not avail itself of exemption because it failed to meet burden of identifying all of its offerees); see also Rule 147(d), 17 C.F.R. § 230.147(d) (1999) (mandating that intrastate offering exemption be conditioned upon all offerees having residence in same state as the issuer's domicile).

59. See 17 C.F.R. $§ 230.506($ b)(2)(ii) (1999). 
Here, the SEC laid the foundation for reform in 1996 with the adoption of Rule $1001,{ }^{60}$ which exempts from Section 5 offerings that are sold only to "qualified purchasers," ${ }^{\circ 1}$ even though the offering involves general advertisements and solicitations. However, the Rule 1001 exemption is confined to offerings not in excess of $\$ 5$ million that are carried out in California. ${ }^{62}$ The next logical step is to accord broad solicitation rights to issuers who will sell their securities only to investors meeting certain criteria, such as that embraced in Rule 1001, and regardless of the size of the offering. ${ }^{63}$ Indeed, there is cause to question why the overall size of the offering should be a factor in defining the scope of any exemption. Exemptions such as the private offering exemption ${ }^{64}$ or an offering to accredited investors ${ }^{65}$ are premised on the offerees being able to fend for themselves, either through their financial sophistication, their bargaining power to obtain relevant information about the offering, or their economic ability to withstand a loss arising from owning the promoted security. So understood, it is difficult to see how any of these criteria are affected by questions of whether the aggregate offering amount is $\$ 5$ million or $\$ 25$ million. Thus, when an offering is sold exclusively to such qualified purchasers, there should not be, as there is under present Rule 1001, any aggregate offering limit. To be sure, a reasonably high offering limit would be necessary for offers carried out pursuant to an abbreviated disclosure procedures, such as Regulation A, that are made to unsophisticated investors. ${ }^{66}$ In such cases, an offering limit serves the purposes of preventing wholesale erosion of instances when full registration is compelled, removing the heavy fixed costs incident to full registration when the issuer needs only a small amount of funds, and minimizing the social damage of any weakness in disclosures that accompany such abbreviated registration. ${ }^{67}$ Thus,

60. See 17 C.F.R. $\$ 230.1001$ (1999).

61. Rule 1001 responded to the request of the State of California that offerings that comply with its version of the private offering exemption would also be exempt from federal regulation. In granting this request, the SEC deferred to California's definition of "qualified purchaser," which includes, inter alia, any person purchasing $\$ 150,000$ of the offered security, persons whose net worth exceeds $\$ 500,000$, and designated institutional purchasers. See CAL. CORP. CODE $§ 25102(n)$ (West 1999).

62. See 17 C.F.R. $\$ 230.1000$ (b) (1999). In its release adopting Rule 1001, the SEC expressed its desire to cooperate with other states that would adopt exemptions incorporating the same standards used by California. It stated that separate consideration would be given to state exemptions similar to, but not exact copies of, the California exemption. See Exemption for Certain California Limited Issues, Securities Act Release No. 7285, 61 Fed. Reg. 21356 (May 1, 1996).

63. The exemption provided by Rule 1001 is limited to offerings that do not exceed $\$ 5$ million and, therefore, is dependent upon the Commission's authority under Section 3(b), 15 U.S.C. § 77c(b) (1994), which authorizes the Commission to provide exemptions to classes of securities to the extent the public interest and the protection of investors are not compromised.

64. See Securities Act $\S 4(2), 15$ U.S.C. $\$ 77 d(2)$ (1994).

65. See Securities Act $\$ 4(6), 15$ U.S.C. $\$ 77 d(6)$ (1994).

66. See Rules 251-263, 17 C.F.R. § 230.251-263 (1999).

67. Thus, Regulation A offerings are not available to companies that are subject to the Exchange Act's continuous reporting requirements. See Rule 251(a)(2), 17 C.F.R. § 230.251(a)(2) (1999). Similar cost-to-proceeds justifications underlie the small issuer registration forms. See Form SB-1 and Form SB-2, which provide a simplified question and answer type disclosure format and overall less burdensome disclosure requirements. 
much can be done to facilitate capital raising when the issuer or its security is of a type that will likely appeal to certain qualified investors.

The next regulatory question is whether some securities by their nature should be exempt from the registration process regardless of the qualities of their purchasers. The Securities Act exempts several types of securities from regulation on the basis of the character of their issuer ${ }^{68}$ constitutional considerations ${ }^{69}$ their issuer being subject to an alternative regulatory regime believed to adequately protect investors, ${ }^{70}$ or on the basis that they do not represent true investments. $^{71}$ An important question is whether a new basis for exemption should be recognized: A security will be exempt because its risks are marketbased, and not issuer-based. The type of securities most readily falling into this category are high-quality corporate debentures and various high grade assetbacked securities. In contrast, no relaxation of disclosure requirements would appear justified for high-yield debentures, more commonly known as "junk bonds," that pose risks that are not unlike common stock, and thus are at the opposite end of the risk spectrum of the high-quality fixed income securities for which an exemption would be considered.

A weaker regulatory consideration here is whether a particular instrument is acquired and traded largely by financial institutions. Securities that are so traded are more easily understood to trade in an efficient market; but recognition of that fact only addresses the manner in which mandatory disclosure rules apply and not whether mandatory disclosure itself is superfluous. On the other hand, for a security whose risks are almost totally shaped by macro-economic events, the disclosure provided by the registration process is at best problematic. The regulatory challenge, therefore, is to design criteria for identifying such securities. This process no doubt will lead the SEC to consider the role that nationally recognized rating agencies might play in such determinations. Thus, the SEC's regulatory objective will likely evolve to establishing criteria that would qualify a rating agency to serve this new gatekeeper function for securities whose performance is driven by macro-economic events.

\section{E. The Reach of Regulation}

It is an internationally recognized principle that the power to proscribe and enforce securities laws is territorial; nations provide regulation for securities transactions conducted within their borders, and their enforcement efforts reach abroad when significant acts giving rise to the violation occur within their country. $^{72}$ United States courts undertake a similar inquiry when deciding ties).

68. See, e.g., Securities Act $\S 3(a)(2), 15$ U.S.C. $§ 77 c(a)(2)$ (1994) (applying to government securi-

69. See id. (obligations of state governments).

70. See Securities Act $\S 3(a)(5), 15$ U.S.C. $\$ 77 c(a)(5)$ (1994) (noting that securities issued by thrift institution regulated by state or federal authority).

71. See, e.g., Securities Act $\S 3(a)(8), 15$ U.S.C. $§ 77 c(a)(8)$ (1994) (applying to insurance policies).

72. The territorial principle of international law calls for determining jurisdiction to prescribe and enforce by reference to the place where the act or offense occurs. See Research in International Law: 
whether to entertain suits by its residents who have purchased securities abroad; jurisdiction in such disputes exists when the defendant has engaged in some preparatory act in the United States in connection with the plaintiff's purchase. $^{73}$ This territorial preoccupation of the securities laws is now undergoing close reexamination. For example, Professors Choi and Guzman call for countries to enter agreements whereby issuers would enjoy portable reciprocity. ${ }^{74}$ Portable reciprocity rests on the premise that issuers would designate in their offering materials the country's disclosure laws with which they would comply in making that offering as well as the country whose laws would govern its continuous disclosure requirements. The country so specified need not be the country where the securities were distributed or traded. Professors Choi and Guzman believe that a regime of portable reciprocity would foster greater regulatory diversity within any market: Issuers and investors would both benefit by a better matching of regulatory burdens with the unique abilities of the issuer to bear those burdens. ${ }^{75}$

Professor Merritt Fox advances quite a different approach: He prefers that the disclosure burden for any issuer be guided by its home country, which he defines as the country of its principal place of business. ${ }^{76}$ He believes that the firm's home country that the greatest interest and sensitivity to the social benefits and costs of the mandatory disclosure requirements. ${ }^{77}$ An important difference in approach between these two proposals is that Professor Fox focuses exclusively on the impact of mandatory disclosure rules on issuers, ${ }^{78}$ whereas Professors Choi and Guzman consider the impact of disclosure requirements on both investor and issuer welfare. ${ }^{79}$ Both proposals, however, depart from the historical territorial orientation of securities laws; both proposals envision that one nation's securities laws could regulate activity that occurs exclusively in another nation.

Elsewhere, I have questioned the wisdom of departing from the territorial orientation of the securities laws on pragmatic and political grounds. ${ }^{80}$ Here, I would like to question the proposal on even more fundamental grounds: If securities laws are not territorially based, we would then have securities laws poorly suited to the purposes they are intended to serve. Classically, securities

Drafts of Conventions Prepared for the Codification of International Law, 29 AM. J. INTL. L. 1, 445 (Supp. 1935). For this principle's application to securities laws, see RESTATEMENT (THIRD) OF FOREIGN RELATIONS LAW OF THE UNITED STATES $§ 416$ (1986).

73. See, e.g., Bersch v. Drexel Firestone, Inc., 519 F.2d 974 (2d Cir. 1975).

74. See Stephen J. Choi \& Andrew T. Guzman, Portable Reciprocity: Rethinking the International Reach of Securities Regulation, 71 S. CAL. L. REV. 903, 922-24 (1998).

75. See id. at 914-18.

76. See Merritt B. Fox, The Political Economy of Statutory Reach: U.S. Disclosure Rules in a Globalizing Market for Securities, 97 MicH. L. REV. 696 (1998); Fox, Who Should Regulate Whom, supra note 27.

77. See Fox, Who Should Regulate Whom, supra note 27, at 2553.

78. See id. at 2587-99.

79. See Choi \& Guzman, supra note 74, at 916-18.

80. See James D. Cox, Regulatory Duopoly for U.S. Securities Markets, 99 ColuM. L. REV. 1200 (1998) [hereinafter Cox, Duopoly]. 
laws are intended to serve a variety of purposes. First, mandatory disclosure seeks to protect investors, by reducing the incidence of fraudulent offerings, and generally arming investors with more information than they would otherwise possess, so that they can make sharper comparisons among competing investment opportunities. Second, the securities laws have the grand objective of nurturing the allocational efficiency of securities markets. Because mandatory disclosure rules are believed to provide more reliable analyses of the amount and timing of future cash flows presented by each issuer, securities laws facilitate a process by which each issuer's costs of capital can be determined relative to that of others. The weaker these laws, the less clear it is that this determination can be made. Third, the securities laws have salutary effects on managerial overreaching. Such opportunistic managerial behavior occurs through shirking, excessive consumption of perquisites, or simply condemning some portion of the fair value of the minority's shares; each was seen as a harmful consequence that would occur in a laissez faire regime. Mandatory disclosure rules are intended to reduce the frequency and magnitude of such behavior. ${ }^{81}$ What then becomes of these three objectives if the securities laws are not focused upon the nation in which the regulatory body sits?

Consider the objective of enhancing allocational efficiency under the proposals advanced by Professors Fox and Choi and Guzman. Surely, if issuers were to enjoy portable reciprocity, both Congress and the SEC would be frustrated in their efforts to shape regulatory policies so that U.S. capital markets would operate at what they believed to be the optimal allocational level. To be sure, portable reciprocity has no impact on regulatory decisions that are inherently indigenous to the market. Thus, issues related to the relative transparency of trading on markets, broker obligations with respect to cueing of orders, exposure of the specialists' order books, and competition among domestic markets are examples of local regulatory issues that are unaffected by a portable reciprocity regime. However, policy decisions informed by concerns of allocational efficiency bearing on the mandatory disclosure requirements for issuers, and presumably decisions by those involved with its distribution as well, would be futile in a portable reciprocity regime. These allocational efficiency policy decisions implicate comparative assessments of securities by investors. To have a regulatory function in this process, the regulator must enjoy a monopoly-like position over the market so that its decisions can affect all market participants. This function is barred in a portable reciprocity regime because, for example, Congress or the SEC can hardly tweak disclosure standards with a view of influencing the allocational function of U.S. markets if those markets are populated in any important way by issuers using non-U.S. disclosure standards. To be sure, the U.S. markets would continue to serve an allocational function; but

81. See John C. Coffee, Jr., Market Failure and the Economic Case for a Mandatory Disclosure System, 70 VA. L. REV. 717, 722 (1984). Cf. Paul G. Mahoney, Mandatory Disclosure as a Solution to Agency Problems, 62 U. CHI. L. REV. 1047 (1995) (arguing that one of the chief objectives of the Securities Act disclosure requirements was to reduce the incidence of managerial abuses arising from their self-interest). 
they would do so free of the policymaker's influence. Under the portable reciprocity approach, markets would return to their pre-New Deal era of unrestrained capitalism.

The allocational efficiency objective becomes even more elusive if we assume that regulators under a portable reciprocity regime would be true internationalists in the sense that they would understand that their disclosure standards would touch issuers and investors who meet in a foreign market. Certainly, as between a French company and a Spanish company vying for capital in London, the U.S.-based regulator would see a weak connection to the allocational efficiency of U.S. capital markets. Moreover, the allocational functions of a market are affected by a host of micro-structural issues, such as order and trade transparency or order cueing rules. As discussed above, these issues are uniquely local so that a regulator in the non-host market, for example, the SEC in the United States, would be even more frustrated if it sought to influence capital raising in a foreign market, such as London, by the disclosure standards it hoped would be used in that foreign market. Without regulatory power over all aspects of the market, the regulator's historical role of influencing the allocational efficiency of the market would be compromised pro tanto.

To be sure, there may be a broader concern that U.S.-based firms would be at a competitive disadvantage if their industry rivals could raise funds more cheaply in London. Not much is to be made of this complaint because currently U.S. firms also may, and do, raise capital abroad with no apparent impact on the perceived efficiency of U.S. capital markets. Their migration provides important competitive pressures on U.S. regulators to rationalize their efforts in the larger global market. Ironically, a portable reciprocity regime would seem to remove this pressure, because migration would not occur. Under portable reciprocity, issuers switch disclosure standards, not markets, with the effect that an important political force is removed from the regulatory process. Thus, portable reciprocity would not only obviate the role of allocational efficiency in the design of mandatory disclosure rules, but would also would remove the one political force that has driven SEC regulatory policies for the past three decades, the pressures of globalization.

The objective of protecting investors from fraudulent offerings would take on curious dimensions in the world of portable reciprocity. A Spanish company offering its securities in London through a fraudulent offering circular poses a minimal threat to U.S. investors. To be sure, in this era of global investing, many of the offering's purchasers are likely to be U.S. residents. Portable reciprocity, however, permits the fraudulent issuer to choose whatever standard it prefers, leaving it to the investor to protect himself by adding a roughly determined discount to reflect the risk of fraud posed by all issuers using the designated disclosure regime. More, however, is involved than the issuer's ability to choose the national standard to which it purports to conform its filings. Investors must also be mindful that a U.S. standard administered and enforced by the United Kingdom's Financial Services Administrator is not the same as a U.S. 
standard in the hands of the SEC. Certainly, there is no empirical basis for assuming that investors systematically make such a sharp judgment; the effect of portable reciprocity may well have the unintended effect of matching U.S. investors with the Spanish issuer in a transaction they otherwise would not have undertaken. Without portable reciprocity, the Spanish issuer would have had to comply with the relatively thorough disclosure standards that apply to securities listed on the London Stock Exchange. A fraudulent issuer, if confronted with such a requirement, may have avoided carrying out an offering in London for this reason, staying in its home Madrid market. That market's high transaction costs for U.S. investors would likely mean that fewer of its shares would be purchased by U.S. residents. However, with portable reciprocity, the fraudulent issuer may gravitate to markets where transaction costs are lower and where there are likely to be more U.S. residents. Thus, it would appear that portable reciprocity is also inconsistent with the U.S. regulatory objective of protecting investors.

An additional concern here is that portable reciprocity recognizes that the role of the regulator is to design securities laws for the possible protection of investors regardless of their nationality or where their trade is executed. Thus, policy judgments are made not with the view toward their benefit to U.S. investors, but investors generally. Certainly, such a mission should make for interesting budgetary hearings before Congress. This observation underscores the importance of garnering political support for any regulatory regime by demonstrating its impact on the politician's constituents. Similarly, the regulatory objective of protecting shareholders from managerial overreaching lacks a discernible political base in the United States when those to be protected are not themselves U.S. residents.

\section{F. Who is the Regulator?}

In the preceding section, the case was made for regulation to remain territorial. Not surprisingly, the status quo is also preferred with respect to who should be the regulator. Possible alternatives to the current system, where the SEC is the supreme regulator, could be regulation by the exchanges or the states.

The proposition that the exchanges would be aggressive, or even vigilant, regulators is becoming a weaker and weaker proposition by the day. ${ }^{82}$ Historically, there is evidence that exchanges, such as the New York Stock Exchange, acted out of their own economic interest and not the public interest. For example, when faced with competitive pressures from NASDAQ, the NYSE relented on its long-held position regarding dual-class voting rights. ${ }^{83}$ Until recently, the NYSE retained its Rule 500 that made it the financial equivalent of the "roach motel." Under former Rule 500, it was very difficult for a company to delist

82. See Paul G. Mahoney, The Exchange as Regulator, 83 VA. L. REV. 1453 (1997).

83. See James D. CoX et Al., Securities Regulation: CASES AND Materials 858-61 (1997) (recounting the history of the SEC's grappling with the one-share one-vote controversy). 
from the NYSE because, among other requirements, Rule 500 conditioned delisting on a super-majority vote of its shareholders. ${ }^{84}$ Further evidence of the NYSE's self-interest is its Rule 390, which barred off-exchange trading by its members in principal transactions for certain listed securities. ${ }^{85}$ Much like former Rule 500, one effect of Rule 390 is to protect the fees that the NYSE derives by trading that occurs through its facilities.

These classic illustrations of exchange regulation driven by self-interest assume heightened importance in today's market. Both the NYSE and NASDAQ are faced with unrelenting competition from alternative trading systems and electronic communication networks ("ECNs"). ${ }^{86}$ The NYSE and the NASD, which owns NASDAQ, are pursuing a strategy of demutualization to meet these competitive pressures. Demutualization would first entail converting memberships into share ownership, followed ultimately by a public sale of interests in the market. Thus, these two markets that have been quasigovernmental public institutions would themselves become publicly traded companies.

The NYSE envisions that demutualization will enhance its independence from its members with respect to its regulatory functions. Its officers would not have to pitch each rule or regulation to its governing body as a manifestation of enlightened self-interest. Demutualization, however, merely substitutes one private interest group for another. The broker-dealers, and later retail investors, who would be shareholders of the NYSE would likely wish the Exchange to pursue profit maximization goals that may not be consistent with regulatory steps that impose burdensome listing requirements on issuers, or drive brokers or dealers to execute their trades elsewhere. To be sure, a strong regulatory culture is an important component of the NYSE's valuable franchise, but its new owners would surely expect tangible proof of this culture in the Exchange's performance in terms of increased listings, trading volume, and profits. There is every reason to believe that demutualization of the NYSE would not yield a strong green light for its regulatory posture, but at least it would sustain the need for each step to be rationalized in terms of its "owners"" self-interest.

The privatization of NASDAQ poses a different set of questions from the demutualization of the NYSE. After transferring NASDAQ to its new owners, the NASD would continue to carry out its regulatory functions as a membership organization. This would essentially return the NASD to the position it enjoyed prior to the creation of NASDAQ. That is the situation Congress envisioned in the Securities Exchange Act by calling for a self-regulatory organization for broker-dealers. Though events may be perceived as returning us to the original

84. See Exchange Act Release No. 40,688, 63 Fed. Reg. 65626 (Nov. 18, 1998) (formal request for approval by the SEC to permit amendment of Rule 500).

85. NYSE Rule 390, as qualified by Exchange Act Rule 19c-3, 17 C.F.R. § 240.19c-3 (1999), lifts restriction of NYSE Rule 390 except for dealers trading as principals in securities listed after April 26, 1979. See Off-Board Trading Restrictions, Exchange Act Release No. 16,888, [1980 Transfer Binder] Fed. Sec. L. Rep. (CCH) II 82,608 (June 11, 1980).

86. Indeed, approximately thirty percent of the volume on NASDAQ now occurs via an ECN. 
model of informed self-regulation, we should still question whether something is being lost by the regulator being separated from the market it purports to regulate. Though the privatization of NASDAQ would separate that market from its regulator, there is reason to believe that this action would not hamper the regulator's vision. The NASD would still be responsible to its broker-dealer members; and that linkage would assure that its committees' staffs would continue to mirror the experiences of its membership. In this way, the role for selfregulatory organizations envisioned by the Exchange Act would not seem to be seriously compromised.

Because private interests would still be present after the demutualization of the NYSE and the privatization of NASDAQ, neither of these developments seems to call for a change in the role of the SEC. The SEC should remain the ultimate arbiter of whether private interests are in conflict with the larger, and paramount, public interest. That is, there is little basis to believe that either demutualization of the NYSE or the public sale of NASDAQ would quell the historical concern that each self-regulatory initiative should serve the public interest.

Professor Roberta Romano believes that the states, and not the SEC, should be the principal guardians of disclosure requirements for U.S. capital markets. ${ }^{87}$ Her approach is based on the view that regulatory competition is more likely to yield optimal disclosure requirements than the monopoly-like status that the SEC currently enjoys. The suggestion that the states, and not the federal government, should become the principal securities regulators lacks any empirical or historical basis. Consider that the most important state in terms of granting corporate charters is Delaware. Delaware corporate law, however, does not require its corporations to produce an annual report for their owners, although many other state corporate laws do. ${ }^{88}$ More troubling yet is that between 1933 and 1995, the states had the power to impose demanding disclosure requirements on public offerings within their states. Instead of doing so, they deferred to federal disclosure requirements by permitting offerings registered with the SEC to proceed in its state either through broad notification or coordination procedures. Thus, Congress' action in $1996^{89}$ to preempt state regulatory efforts for certain types of issuers effectively federalized the de facto preemption that had existed for decades..$^{90}$ One should, therefore, ask just where we would find

87. See Roberta Romano, Empowering Investors: A Market Approach to Securities Regulation, 107 YALE L.J. 2359, 2365-72, 2388-91, 2408-10 (1998).

88. Fifteen states presently require corporations to furnish financial statements annually to their shareholders and another twenty-five require such statements to be provided upon request. See M.B.C.A. Ann. § 16.20 at 16.77 (Supp. 1997).

89. See National Securities Market Improvement Act of 1996, Pub. L. No. 104-290, 110 Stat. 3416 (1996) (amending Section 18 of the Securities Act, 15 U.S.C. $§ 77$ r (1998), so as to preempt state blue sky registration procedures for "covered securities").

90. For a description of the state's accession to SEC regulation through their notification and coordination procedures, see Report on State Merit Regulation of Securities Offerings by the Ad Hoc Subcommittee on Merit Regulation of the State Regulation of Securities Committee, American Bar Association, 41 BUS. LAW. 785, 798-800 (1986). 
the state's commitment to provide regulation in this area. More important, where would we find the political will to reverse the steps Congress took in 1995 to remove the states' powers over securities transactions that are national in scope.

An even stronger case for keeping the SEC as the supreme U.S. regulator can be made on international principles. Contrary to Professor Romano's premise that U.S. securities regulation suffers from a lack of competition, competition is evident in nearly every decision the SEC has reached in the past two decades. Whether it be the adoption of integrated disclosure procedures, ${ }^{91}$ Rule $144 \mathrm{~A},{ }^{92}$ or its recent approach to the regulation of alternative trading systems, ${ }^{93}$ the SEC has demonstrated a healthy appreciation and rationalization that securities offerings and trading occur globally. Absent a highly competitive London, and ultimately Frankfurt, market, the SEC today would find little need to give serious consideration to allowing foreign issuers to report financial information according to International Accounting Standards ("IAS") rather than reconciling their foreign-based financial reports to U.S. GAAP. However, competition from foreign markets and the quest for secondary listings for U.S. exchanges have caused the SEC to expend nontrivial resources to move the development of IAS forward for use in SEC filings. ${ }^{94}$ Thus, competition does not exist with the states, but it does exist with respect to important foreign markets and regulatory bodies such as the IAS Committee.

The SEC is a highly credible voice in the international community with respect to securities regulation. Indeed, it has been an international leader in advancing the cause of securities regulation. I have discussed elsewhere the natural tendency of nations to build their own regulatory efforts around the practices and vision of a dominant nation. ${ }^{95}$ Nations do so because of high coordination costs that they would incur to develop a separate regulatory paradigm. Their adoption of the dominant nation's regulatory stance also leads to quicker resolution regarding the approach each nation can take, in addition to harmonizing practices among nations with concomitant efficiencies. The SEC, through a variety of mechanisms, has been the dominant force in shaping regulatory approaches internationally. It would be difficult to imagine this function being performed by Delaware.

91. See Adoption of Foreign Issuer Integrated Disclosures Form, Securities Act Release No. 19,258, 26 SEC Docket 964 (Nov. 19, 1982).

92. See 17 C.F.R. § 230.144A (1999), adopted in Securities Act Release No. 6862, 55 Fed. Reg. 20,894 (Apr. 23, 1990) (A resale safe harbor for certain unregistered securities where sales are made to qualified institutional buyers, as defined in the rule).

93. See Regulation of Exchanges \& Alternative Trading Systems, Exchange Act Release No. 40,760; 68 SEC Docket 225 (Dec. 8, 1998); Regulation of Exchanges, Exchange Act Release No. 38,672, 62 Fed. Reg. 30,485 (May 23, 1997).

94. See SEC, Report on Promoting Global Preeminence of American Securities Markets 12 (visited Dec. 12, 1997) <http://www.sec.gov/news/studies/acctgsp.htm>.

95. See Cox, Duopoly, supra note 80, at 1237-38. 
III

\section{THE REACH OF THE SEC's EXEMPTIVE AUTHORITY}

The SEC's broad regulatory powers over securities offerings lie in the rulemaking authority granted by both the Securities Act and the Exchange Act. The SEC's powers cover a wide variety of regulatory issues, such as prescribing the information to be included in the registration statement, ${ }^{96}$ the identification of the applicable financial reporting standards for SEC filings, ${ }^{97}$ and the determination of what conduct shall be unlawful because it has been defined in its rules as "fraudulent," "manipulative," or "deceptive." Though the Securities Act and the Exchange Act confer broad rulemaking authority on the SEC to define the Acts' terms and to carry out certain regulatory mandates, the SEC's exercise of these powers nevertheless must be consistent with the power Congress has granted. Chevron U.S.A. v. Natural Resource Defense Council pro-

96. See Securities Act $\S 7(a), 15$ U.S.C. $\S 77 \mathrm{~g}$ (1994). The structure of the Securities Act is indicative of the breadth of the SEC's authority over the contents of the registration statement. In Section 7(a) the Securities Act first states that the registration statement "shall contain the information, and be accompanied by the documents" set forth in Appendix A of the Act. However, later language empowers the Commission to exercise its rule-making authority to exempt any class of issuers from the disclosures called for in Appendix A when the Commission "finds that the requirement of such information or document is inapplicable to such class [of issuer] and that the disclosure fully adequate for the protection of investors is otherwise required to be included in the registration statement." Id. Later, the provision empowers the SEC to require the registration statement to "contain such information ... as the Commission may by rules or regulations require as being necessary or appropriate in the public interest or for the protection of investors." Broader still is the reference in Section 19(a), 15 U.S.C. $77 \mathrm{~s}(\mathrm{a})$ (1994), to the Commission's power to engage in rule making "as may be necessary to carry out the provisions of this Act, including rules and regulations governing registration."

97. See Securities Act $\S 19(a), 15$ U.S.C. $\S 77 \mathrm{~s}(\mathrm{a})$ (1994). Of special interest on the issue of the breadth of the SEC's exemptive authority is the validity of the SEC's delegation of its authority over accounting principles that are to be used in SEC filings to the Financial Accounting Standards Board ("FASB"). In Accounting Series Release 150 (1973), the SEC recognized that issuers whose disclosures conformed to the pronouncements of the then newly-created FASB would be deemed to have been reported in a manner that had substantial authoritative support such that those disclosures were presumed not to be misleading. Financial statements not conforming to FASB directives would be deemed to have used disclosure standards that lacked substantial authoritative support and, therefore, would not enjoy the presumption. In Arthur Andersen \& Co. v. SEC, a major accounting firm challenged the position taken by the SEC in ASR 150 as an impermissible delegation of rulemaking authority to an outside private agency, the FASB. [1978 Transfer Binder] Fed. Sec. L. Rep. (CCH) II 96,374 (N.D. Ill. 1978). The suit was dismissed on the ground that the plaintiff failed to establish how it would be harmed by complying with ASR 150 so that it lacked standing to challenge the SEC's deferral to the FASB on the establishment of generally accepted accounting standards. Id. at 4-7.

98. There are many examples of the SEC's power to define what constitutes fraudulent, manipulative, or deceptive practices. Of special interest for this article is how the SEC has used its rulemaking authority to shape the public offering process. For example, Section 15(c)(2)(D), 15 U.S.C. § $78 \mathrm{o}(\mathrm{c})(1)(\mathrm{D})$, confers on the SEC power to set forth regulations designed to prevent acts or practices by certain brokers or dealers that otherwise would be fraudulent, manipulative, or deceptive. Pursuant to this provision, the SEC has promulgated a rule requiring the broad circulation of the prospectus among distribution participants. See Rule 15c2-8, 17 C.F.R. $\$ 240.15$ c2-8 (1999). In Regulation M, Rules 100-105, 17 C.F.R. 242.100-242.105 (1999), the SEC regulates purchases during a distribution and sets forth requirements for stabilization efforts during the public offering of a security. In addition to relying on its rule making authority in Section 15(c) when it adopted Regulation M, the SEC also invoked its powers under Section 17(a) of the Securities Act, 15 U.S.C. $\$ 77 q(a)$ (1994) and Sections 9 and 10(b) of the Exchange Act. 15 U.S.C. $\S \S 78 \mathrm{i} \& 78 \mathrm{j}(\mathrm{b})(1994)$.

99. 467 U.S. 837 (1984). 
vides the contemporary framework for judging whether a federal agency, such as the SEC, has acted beyond the scope of its rulemaking authority. The Supreme Court's decision in Chevron first requires that the reviewing court determine whether Congress has "directly spoken to the precise question at issue." 100 This inquiry calls for an examination of the statutory language and, if necessary, any relevant legislative history. If the Congressional intent is not clear, the court must then determine if the agency's interpretation is a "permissible" one. ${ }^{101}$ The flexible Chevron framework, therefore, recognizes that it is the agency, and not the reviewing court, which holds primary responsibility for interpreting the statute. Under Chevron, the reviewing court cannot substitute its judgment for that of the agency. The court cannot, for example, reject an agency's rule because the court doubts the rule's wisdom. ${ }^{102}$ The central premise underlying the deference mandated by Chevron is that the reviewing court determines that Congress has delegated administrative authority to the agency. ${ }^{103}$ Deference thus turns on whether the reviewing court has a basis for its belief that Congress intended to delegate policymaking power to the agency. ${ }^{104}$

Few decisions have seriously questioned the validity of an SEC rule. In Greene v. Dietz, ${ }^{105}$ the Second Circuit questioned the validity of an SEC rule exempting the exercise of an employee stock option from the Exchange Act's short-swing profit provision. The court reasoned that the purpose of the enabling provision was to discourage the abuse of inside information by officers and directors of publicly traded companies, and that it was possible that such an abuse could occur within the terms of the challenged exemptive provision. Hence, the court believed that there was a reasonable basis to conclude that the rule did not carry out the purposes of the enabling provision. The continuing validity of Greene has been undermined by Chevron, because of Chevron's threshold requirement that the reviewing court first determine whether Congress intended to confer policymaking power on the SEC by granting it authority to craft exemptions to the short swing profits provision ${ }^{106}$ rather than inquiring, as was the approach in Greene, whether the exemption covered only instances in which no abuse of insider information could occur.

The most serious reversal in the SEC's long history of rule making occurred with the invalidation of its one-share/one-vote rule by the Court of Appeals for the District of Columbia in The Business Roundtable v. Securities and Exchange

100. See id. at $842-43$.

101. See id. at 843.

102. See, e.g., Investment Company Inst. v. Conover, 790 F.2d 925, 935 (D.C. Cir. 1986). Chevron's impact is all the more evident considering that the Administrative Procedure Act would appear to lead to a different approach, because it provides that the reviewing court is to decide "all relevant questions of law." 5 U.S.C. $\$ 706$ (1994).

103. See, e.g., Adams Fruit Co. v. Barrett, 494 U.S. 638, 649 (1990).

104. See, e.g., Pauly v. Bethenergy Mines, Inc., 501 U.S. 680, 696 (1991).

105. 247 F.2d 689, 693-94, 697 (2d Cir. 1957).

106. The SEC has broad rule making powers under Exchange Act $\S 16(\mathrm{~b})$, to exempt transactions "not comprehended within the purpose of this subsection." 15 U.S.C. § 78p(b)(1994). 
Commission. ${ }^{107}$ The New York Stock Exchange and the American Stock Exchange for many years had imposed a one-share/one-vote policy as part of the governance rules upon which listing was conditioned. With the rise of the frequency of hostile takeovers in the 1980s, corporate managers sought protection against unwanted suitors. Corporate managers focused their interest on the possibility of issuing shares with super voting rights to themselves and their supporters. The managers' rising interest in super voting shares coincided with NASDAQ's emergence as a meaningful competitor to the established exchanges; NASDAQ, unlike the New York Stock Exchange and the American Exchange, did not have a one-share/one-vote requirement. With the exchanges poised to join NASDAQ in permitting super voting shares to be listed, the SEC adopted Rule 19c-4, not only to preserve the long-standing practices of the exchanges not to list shares if voting rights within that class of shares were substantially unequal, but also to expand this policy to NASDAQ traded shares.

In defending its rule, the SEC relied chiefly upon its authority under Section 19(c) ${ }^{108}$ of the Exchange Act to adopt rules with respect to three broad areas: rules concerning the "fair administration" of the self-regulatory organization, rules calling for the self-regulatory organization "to conform its rules or requirements" to the Exchange Act, and rules "otherwise in furtherance of the [Act's] purposes." ${ }^{109}$ The SEC argued that Rule 19c-4 was "in furtherance of the purposes" of Section 14(a) of the Exchange Act, which authorizes the SEC to adopt rules regulating proxy voting. ${ }^{10}$ The court rejected this argument, reasoning that the clear purpose of Section 14 was to empower the SEC to regulate the disclosures that accompany proxy solicitations and the process of proxy voting, but not to adopt substantive governance questions, such as how corporate participants may choose to arrange their relationships.

The court believed that Congress intended that the substantive rights of shareholders should remain, as they had been, in the exclusive province of state regulatory power. ${ }^{111}$ The SEC was also unsuccessful in justifying Rule 19c-4 by referring to its powers under Sections 6(a)(5) and 15A(b)(6) of the Exchange Act to adopt rules designed "in general" to "protect investors and the public interest," 112 because the court concluded that the SEC's general authority was qualified by a larger list of specific standards in those sections regarding the operation and administration of the self-regulatory organizations. ${ }^{113}$ Moreover, the court held that the SEC's power to act in the "public interest" was not unbounded. The statute's "public interest" standard requires an agency to invoke not just any policy justification for its action, but rather a public policy of the

107. 905 F.2d 406 (D.C. Cir. 1990).

108. 15 U.S.C. $\$ 78$ s (1994).

109. Securities Exchange Act of 1934 § 19(c), 15 U.S.C. § 78s (1994).

110. See Business Roundtable, 905 F.2d at 410.

111. See id. at 411.

112. 15 U.S.C. $§ \S 78 f(a) \& 78 o-3(b)(6)$ (1994).

113. See Business Roundtable, 905 F.2d at 413. 
type Congress envisioned as being within the special province of that agency. ${ }^{114}$ Because Congress never intended the SEC to have the power to preempt state jurisdiction with respect to the law of corporate organizations, the court reasoned that the SEC could not invoke public interest considerations in order to federalize substantive corporate governance requirements through Rule 19c-4. Similarly, the court concluded that the broad mandate in Section 11A(a)(2) "to facilitate a national market system" was restrained by language in the legislative report that this mandate was not intended to "transform the SEC into an economic czar." 115

The proposed changes called for in Part II of this article are deregulatory in nature; they do not raise the same substantive issues that confronted the SEC in The Business Roundtable. Overall, the rule changes proposed in Part II of this article involve issues of retrenchment of regulatory authority, not encroachment upon the jurisdiction of the states or of another regulator. Additionally, nearly all of the changes recommended in Part II do not raise the more troubling issue under Chevron of whether it is proper for the court to defer to an administrative agency's judgment regarding the reach of its jurisdiction. ${ }^{116}$ The liberalizations called for in Part II, instead, call upon the SEC to confine the scope of Section 5 of the Securities Act through a series of regulatory initiatives.

The initiatives posing the least problem under Chevron are those that involve the SEC exercising its rule making powers to define terms used in the Act, such as "offer to sell" and "prospectus," pursuant to the general rule making powers of Section 19(a) of the Securities Act. ${ }^{117}$ Thus, the earlier proposals related to gun-jumping considerations and permitting sales to be consummated without the formal delivery of information set forth in the registration statement would appear to be well within the SEC's power. For such deregulatory initiatives, Chevron's first step appears to be satisfied, because Congress clearly has granted the SEC authority to define the operative terms of the Securities Act. ${ }^{118}$

By far, the most challenging deregulatory step, in terms of the ability of the SEC to take action without further congressional mandate, is the step that needs to be taken for a true company registration process. As discussed earlier, a workable company registration system requires important modifications in the scope of Section 11 responsibilities for underwriters and outside directors. The modifications called for in Part II would narrow the areas of the registration

114. See id.

115. Id. at 416.

116. Compare New York Shipping Ass'n v. Federal Maritine Comm'n, 854 F.2d 1338, 1363 (D.C. Cir. 1988) and National Wildlife Fed'n v. I.C.C., 850 F.2d 694, 699 n.6 (D.C. Cir. 1988) with Commodity Futures Trading Comm'n v. Schor, 478 U.S. 833, 845 (1986) (holding that deference extends to an agency's decision regarding the scope of its jurisdiction).

117. See Securities Act $\$ 19(a), 15$ U.S.C. $\$ 77 s(a)(1994)$.

118. Securities Act $\S 19(a), 15$ U.S.C. $\$ 77 s(a)$ (1994), may at first suggest the SEC's power extends only to "defining accounting, technical and trade terms used in the Act." However, preceding that phrase is language clearly indicating this is a non exclusive list and that other rules are permissible provided that they are believed "necessary to carry out the provisions" of the Act. 
statement for which the underwriters and the outside directors must undertake a reasonable investigation in order to establish their due diligence defense under Section 11(b). Here, the SEC may well draw upon its authority under Section 7(a) to delineate the contents of the registration statement. ${ }^{119}$ However, Congress appears to have intended only that Section 7(a) empower the SEC to prescribe what disclosures issuers or classes of issuers should make for the benefit of investors. The language of Section 7(a) poorly supports the interpretation that the SEC has the power to delineate, for Section 11 liability purposes, categories within the information required for a registration statement, so that some parties have due diligence responsibilities for only portions of the registration statement whereas other parties are liable for all disclosures made in the registration statement. For such a sweeping change in liability rules for public offerings, the SEC must rely upon its exemptive authority under Section 28 that was added to the Securities Act by the National Securities Markets Improvement Act of $1996 .{ }^{120}$

Section 28 provides the broadest example of the exemptive authority that the SEC enjoys under the securities laws:

The Commission, by rule or regulation, may conditionally or unconditionally exempt any person, security, or transaction, or any class or classes of persons, securities, or transactions, from any provision or provisions of this title or of any rule or regulation issued under this title, to the extent that such exemption is necessary or appropriate in the public interest, and is consistent with the protection of investors. ${ }^{121}$

Assuming that the public interest is adequately served by reducing the time for securities offerings by seasoned companies, and that investor protection is enhanced (or at least not weakened) if, for example, the underwriter's Section 11 liability were confined to discrete portions of the registration statement, a rule limiting the underwriter's liability would appear to be within the sweeping language of Section 28. Supporting this interpretation are broad statements in the Act's accompanying House Report stating that the exemptive authority is intended to "promote efficiency, competition and capital formation," the Senate Report that the new "exemptive authority would make it easier for the SEC to implement certain proposals to facilitate capital formation, such as ... the 'company registration' proposals to assist large businesses." ${ }^{123}$ The only suggestion that Section 28 may not empower the SEC to alter the present due diligence requirements of Section 11 are the isolated remarks of Congress-

119. See 15 U.S.C. $§ 77 \mathrm{~g}(1994)$.

120. 110 Stat. $3416(1996)$.

121. 15 U.S.C. $\$ 77 \mathrm{z}-3$ (Supp. 1998).

122. H.R. Rept. No. 622, 104th Cong., 2d Sess. 41 (1996).

123. S. Rep. No. 293, 104th Cong., 2d Sess. 16 (1996). Presumably the company registration proposals are those set forth in the Report of the Advisory Committee on the Capital Formation and Regulatory Processes. See Wallman Commission Report, supra note 31. The Advisory Committee's proposals, however, do not reduce the scope of the directors' or the underwriters' Section 11 responsibilities as recommended in Part II of this article. 
man John Dingell that the "bill does not grant the SEC the authority to grant exemptions from the antifraud provisions of either act."

Though the isolated remarks of a single congressman are hardly probative of Congress's intent, the express language of Section 28 is. If the SEC were to rely upon Section 28 to streamline the offering process, any relaxation of the requirements of Section 11 must satisfy Section 28's mandate that the exemption is "consistent with the protection of investors." Certainly, when Congress enacted the Securities Act in 1933, it believed that demanding liability standards were a necessary concomitant for investor protection. It is on this point that Congressman Dingell's observations have their greatest resonance.

The strength of the company registration system recommended in Part II does not stem from a desire to make the directors' or underwriters' lives easier, although that possibility may introduce efficiencies into the offering process that redound to the benefit of the public interest. As envisioned in Part II, due diligence requirements for many parts of the Exchange Act filings that are incorporated into the Securities Act registration statement would occur periodically rather than episodically with the public offering of securities. The view here is that a true company registration system separates the offering process from the information verification process. The more straightforward manner to do this would be for the SEC to exercise its rule making authority to narrow considerably those portions of the registration statement for which directors and underwriters are responsible. In doing so, the SEC could substantially lighten the burdens of the registration process for seasoned issuers. ${ }^{125}$

However, if the SEC only acted to reduce the scope of the registration statement for which the directors and underwriters bore responsibility, the SEC would be giving up one of the benefits of the integrated disclosure system-improving the quality of Exchange Act reports by expanding Section 11 responsibilities to information in those reports to the extent that they are incorporated into the issuer's registration statement. Yet, such a step might still be justified by invoking the problematic nature of its assessing whether improvement in the quality of Exchange Act reports for seasoned issuers as a result of integrated disclosure has, in fact, occurred.

124. 142 Cong. Rec. E1938-05, (daily ed. Oct. 21, 1996) (statement of Rep. Dingell), available at 1996 WL 602735 (Oct. 21, 1996). Congressman Dingell further states that "Congress has expressed the public interest through the express provisions of law that it has enacted. The SEC may not administratively repeal these provisions by use of the new exemptive authority." Id. In contrast, the remarks of Congressman Thomas J. Bliley, Jr. recognize that Congress has in other provisions granted the SEC authority to exempt parties from liability for insider trading, implying that the SEC's power under Section 28 extends to lifting liability under the antifraud provisions. See 142 Cong. Rec. E1928-01 (daily ed. Sept. 28, 1996) (statement of Rep. Bliley), available at 1996 WL 565810 (Sept. 28, 1996).

125. Under Chevron, deference is accorded the agency's decisions upon finding that Congress intended the agency to balance sometimes competing objectives that Congress would be involved in the exercise of the delegated policy making authority. See Michigan Citizens for an Indep. Press v. Thornburgh, 868 F.2d 1285, 1293 (D.C. Cir. 1989), aff'd by equally divided Court, 493 U.S. 38 (1989) (deferring to Attorney General's determination regarding an exemption under the Newspaper Preservation Act where interest of fostering diverse editorial voices had to be weighed against economic conditions within the industry). 
A review of recent data on the profile of companies that have been prosecuted for fraudulent reporting practices reveals that very few such cases involve firms that are eligible to take advantage of the SEC's integrated disclosure procedures. ${ }^{126}$ On the other hand, the social value of the present integrated disclosure system could well be substantiated by the same data. After all, one of the perceived benefits of the enhanced liability standards for mandated disclosures for public offerings is the belief that this process reduces the frequency of fraudulent practices generally. Certainly, there is at least intuitive appeal that the expansion of Section 11 responsibilities to Exchange Act reports likely has improved the overall quality of those reports; the only reservation may be whether the overall benefits of such an improvement justify the cost of their achievement. Because the exemption must meet both a "public interest" and a "protection of investors" standard under Section 28, the exemption could not be justified solely on the ground that the present regulatory scheme poses costs in excess of any perceived benefits. Any exemption that removes recognized investor protection benefits without adding at least some other protections in its place is clearly inadequate. Indeed, this would seem to be the very judgment Congress has reserved for itself and has made in Section 11.

A central component of the company registration proposals in Part II is the subjection of Exchange Act reports to periodic due diligence reviews by the company's senior officers and directors. That is, an important initial step toward lightening the regulatory demands triggered by the registration process would be to transform those demands to periodic undertakings by seasoned issuers and their insiders to review the registrant's most recent Exchange Act reports. In practice, the review would be carried out by the issuer's consultants, such as its attorneys or investment banker. Such a review would more systematically assure improvement in the quality of Exchange Act reports, certainly as to those reports that were the subject of such a review.

It is not likely that this regulatory change in the offering process can occur without new legislative authority. The best hope of accomplishing this change under Section 28 would be to link the relaxation of Section 11 obligations "conditionally" upon an express undertaking of heightened liability for Exchange Act reports. Even though this justification mirrors Section 28's language, it nevertheless faces formidable challenges to its validity. The proposed rulemaking would constitute a significant alteration of the balance between the Securities Act and the Exchange Act. The express liability standards of the Securities Act clearly invoke a negligence standard whereas no negligence standard, is recognized for the Exchange Act's antifraud provisions. ${ }^{127}$

126. See Accounting Industry Group Releases Fraud Study, supra note 24.

127. This position was first taken for private suits in Ernst \& Ernst v. Hochfelder, 425 U.S. 185 (1976), and has been extended to SEC enforcement actions in SEC v. Aaron, 446 U.S. 680 (1980). For a critique of how the Supreme Court could have upheld a negligence standard for Section 10(b), see James D. Cox, Ernst \& Ernst v. Hochfelder: A Critique and Evaluation, 28 HASTINGS L.J. 569 (1977). The Court has also concluded that the Williams Act's antifraud provision, Section 14(e), 15 U.S.C. $\S$ $78 \mathrm{n}(\mathrm{e})$ (1999), also requires proof of scienter. See Schreiber v. Burlington Northern, Inc., 472 U.S. 1 
It is doubtful that such a global shift in liability standards could be achieved under the current general grant of exemptive powers. Indeed, this regulatory thrust may be seen not as an exemption, but instead as an expansion of regulatory power. Just as The Business Roundtable saw the SEC encroaching on the states' control over substantive corporate law, ${ }^{128}$ an exemption raising the responsibilities of parties with respect to Exchange Act filings would be seen as invading Congress' repeated commitments to a scienter standard for conduct regulated by the Act. It would therefore appear that a true company registration process is not achievable under the SEC's current exemptive authority.

We thus find an ironic twist with respect to the scope of the SEC's exemptive authority. The above analysis concludes that the SEC could exercise its regulatory powers to reduce the scope of the Section 11 responsibilities significantly by defining the meaning of "registration statement" for the purposes of the defenses available to certain parties under Section 11(b) of the Securities Act. However, a regulatory effort to balance such a lightening of Section 11 responsibilities by substituting periodic, for instance trienial, due diligence requirements for portions of the registrant's Exchange Act reports would appear beyond the scope of Section 28, and in conflict with Congress' intention for the scope of the anti-fraud provisions with respect to matters governed by the Exchange Act. An effective company registration system requires the separation of many of the responsibilities under Section 11 from the act of offering the securities-a choice not available to the SEC under its current rulemaking power-in order to increase the liability standards for seasoned issuers with respect to the Exchange Act reports. The SEC may, however, consider increasing the quality of Exchange Act reports by increasing the resources it now devotes to their review and close examination. It could also couple this effort with the suggestions in Part II that the SEC set forth meaningful due diligence safe harbors for outside directors and underwriters. Each of these steps would surely improve the current regulation of public offerings by seasoned companies.

IV

\section{CONCLUSION}

As seen in Part II, the regulatory framework for public offerings embraced in 1933 with the enactment of the Securities Act has withstood the dramatic transformations that have taken place over the past seven decades. This is because the regulatory tenets of the Securities Act, such as a central federal regulator, the filtration process, and the broad rulemaking powers granted to the SEC, have provided the flexibility necessary for the Act to renew itself periodically. Its last renewal was the adoption of the integrated disclosure procedures in 1982. The time is ripe for another sweeping renewal. As seen in Part III,

(1985). Relevant to the scope of the SEC's power to alter the liability standard for misleading documents in SEC filings is Section 18 of the Exchange Act, 15 U.S.C. \$78r (1994), which imposes liability unless the defendant establishes her lack of "knowledge" that the filing was misleading.

128. See supra notes 112-14 and accompanying text. 
most of these changes are well within the power of the SEC to carry out. Important steps toward a company registration system would be available for seasoned issuers. Such deregulatory steps pose no serious threat to investor protection, and would achieve the important objective of reducing the regulatory costs for capital formation in the United States. 